\title{
EFEKTIVITAS PROMOSI PANTAI PAPUMA JEMBER MELALUI MEDIA JEJARING SOSIAL
}

\author{
Bagus Indra Tjayadhi \\ Dosen Akademi Pariwisata Muhammadiyah Jember \\ Email: goez@akparmuhjember.ac.id
}

\begin{abstract}
ABSTRAK
Media jejaring sosial di internet saat ini semakin berkembang jenis dan ragamnya termasuk manfaat dan tujuannya. Media yang awalnya hanya digunakan untuk pertemanan di dunia maya berkembang menjadi salah satu media cukup populer untuk mempromosikan sesuatu pada saat ini. Fenomena ini juga mempengaruhi cara promosi dari Pantai papuma. Pantai tersebut merupakan salah satu objek wisata terkenal di Kabupaten Jember yang dikunjungi banyak wisatawan. Hal ini sangat berguna bagi wisatawan yang ingin mengunjungi Pantai Papuma, karena mereka bisa mendapatkan informasi dengan mudah mengenai objek wisata melalui facebook, blog, dan jenis media jejaring sosial lainnya. Dalam penelitian ini tingkat efektivitas promosi diukur dengan menggunakan teknik model EPIC dengan menggunakan variabel empati, persuasi, dampak dan komunikasi. Tingkat EPIC dari hasil penelitian ini adalah sebesar 4,03. Skor ini menunjukkan bahwa media jejaring sosial cukup efektif dalam mempromosikan Pantai Papuma kepada masyarakat.
\end{abstract}

Kata Kunci: media jejaring sosial, promosi, EPIC Model. 


\section{PENDAHULUAN}

Pariwisata saat ini telah menjadi salah satu sektor pendapatan daerah yang cukup potensial, mengingat kegiatan kepariwisataan senantiasa melibatkan berbagai komponen masyarakat mulai dari usaha kelas mikro hingga kelas menengah, sehingga komponen tersebut akan saling menggerakkan roda perekonomian di masyarakat. Aktivitas kepariwisataan yang terdiri dari melihat sesuatu yang dalam hal ini adalah berkaitan dengan daya tarik wisata, melakukan aktivitas kegiatan pada saat berada di objek wisata dan pada akhirnya wisatawan akan melakukan transaksi pembelian dilokasi objek wisata tersebut.

Faktor jumlah kedatangan wisatawan dan lama tinggal wisatawan merupakan beberapa faktor yang mempengaruhi meningkatnya jumlah transaksi yang yang terjadi pada daerah wisata tersebut. Diperlukan berbagai upaya untuk meningkatkan jumlah kunjungan wisatawan pada suatu daerah maupun objek wisata, salah satunya adalah pihak pengelola harus melakukan promosi terus menerus di berbagai bentuk media sehingga informasi kepada calon wisatawan menjadi semakin banyak, lengkap dapat dengan mudah untuk diakses dimanapun dan kapanpun.

Kegiatan promosi dapat dilakukan dalam berbagai bentuk, baik secara langsung maupun tidak langsung. Salah satu bentuk promosi tidak langsung yang dapat dilakukan adalah menggunakan iklan. Iklan merupakan proses komunikasi yang bertujuan untuk membujuk atau menggiring orang untuk mengambil tindakan menguntungkan bagi pihak pembuat iklan (Durianto, Darmadi dan Liana dalam Riyantoro, 2013). Kotler dalam Riyantoro (2013) menyatakan bahwa tujuan periklanan dapat digolongkan berdasarkan sasarannya yaitu apakah untuk menginformasikan, membujuk atau mengingatkan. Selain bentuk promosi yang harus ditentukan, hal yang harus diperhatikan berikutnya adalah pemilihan media dalam beriklan. Media untuk beriklan sangat banyak ragam dan jenisnya, tetapi di era teknologi modern pada sekarang ini pemilihan media internet dalam beriklan merupakan salah satu strategi pemasaran yang efektif dan efisien. Biaya terjangkau dan jangkauan internet yang luas merupakan beberapa faktor yang melatarbelakangi perusahaan untuk beriklan di internet.

Media internet dalam perkembangannya mendukung adanya fasilitas jejaring sosial seperti facebook, twitter dan bentuk media jejaring sosial lainnya yang memungkinkan pengguna internet saling terhubung satu dengan lainnya. Jejaring sosial ini kemudian menjadi situs yang populer dimanfaatkan masyarakat Indonesia. Berdasarkan data yang diakses dari situs www.tekno.kompas.com menjelaskan bahwa sampai dengan akhir tahun 2014 pengguna twitter mencapai 50 juta dan pengguna facebook di Indonesia mencapai sekitar 77 juta. Hal ini yang kemudian dilihat sebagai peluang besar oleh pengguna baik yang berbentuk perusahaan maupun perseorangan untuk memilih jejaring sosial sebagai media pemasaran di internet untuk memasarkan produk yang dimiliki. Selain itu banyak kelebihan lain yang dimiliki oleh jejaring sosial ketika digunakan dalam kegiatan pemasaran seperti halnya kemudahan melakukan komunikasi interaktif dengan calon pembeli, tidak membutuhkan keahlian khusus dalam menggunakan media tersebut dan tidak memerlukan biaya tinggi seperti halnya ketika memasarkan produk melalui website resmi yang dikelola secara mandiri.

Pantai Papuma sebagai salah satu objek wisata andalan di Kabupaten Jember masih harus diperkenalkan pada masyarakat luas baik di dalam maupun luar negeri. Didukung dengan fenomena alam seperti pasir putih, batu - batu besar disekeliling pantai dan ombak khas laut pantai selatan merupakan fenomena alam yang memiliki daya tarik tersendiri. Pihak 
pengelola telah melakukan berbagai upaya untuk mengundang lebih banyak wisatawan agar berkunjung ke Pantai Papuma, salah satunya dengan melakukan promosi melalui media internet, khususnya media jejaring sosial. Kemudahan memperoleh informasi melalui media jejaring sosial merupakan salah satu faktor yang meningkatkan movitasi wisatawan untuk berkunjung ke Pantai Papuma, karena dengan kemudahan tersebut membuat wisatawan mampu mengambil keputusan berdasarkan cerita, pengalaman dan data berupa gambar yang disajikan melalui media jejaring sosial.

Berdasarkan fenomena strategi pemasaran inilah yang menjadi dasar pemikiran untuk meneliti efektivitas iklan melalui media jejaring sosial. Ada beberapa metode yang dapat digunakan untuk melihat efektifitas suatu iklan berdasarkan dampak komunikasi yang ditimbulkan, yaitu : CRI (Customer Response Index), DRM (Direct Rating Method), EPIC Model, dan CDM (Consumer Decision Model). Dalam EPIC Model terdapat empat dimensi kritis sebuah iklan yaitu empathy, persuation, impact, dan communication untuk kemudian dianalisa guna melihat efektifitas masing-masing dimensi tersebut secara terpisah sehingga dapat diketahui pada dimensi yang manakah sebuah iklan memiliki kelemahan dalam pencapaian tujuannya dan selanjutnya merancang strategi baru untuk memperbaiki kelemahan tersebut.

\section{METODE}

Penelitian ini dilakukan di objek wisata Pantai Papuma di Kabupaten Jember. Penelitian ini dirancang sebagai penelitian eksplanasi atau penelitian penjelasan yaitu penelitian yang menjelaskan hubungan antar variabel melalui pengujian hipotesis (Singarimbun dan Effendi, 1995:256). Penelitian ini menjelaskan pokok bahasan tentang efektivitas promosi Pantai Papuma melalui media jejaring sosial. Data primer di penelitian ini merupakan data yang diperoleh langsung dari responden yaitu wisatawan yang berkunjung ke Pantai Papuma. Data sekunder diperoleh dari literatur, jurnal maupun kajian empiris pendukung penelitian serta dokumen lain. Analisis data dalam penelitian ini menggunakan EPIC Model yang dimaksudkan untuk mengetahui tingkat efektivitas promosi Pantai Papuma melalui media jejaring sosial. Durianto dalam Priadi (2010) menjelaskan bahwa Metode EPIC Model adalah salah satu alat ukur yang digunakan untuk mengukur efektivitas iklan dengan pendekatan komunikasi yang dikembangkan oleh AC Nielsen, salah satu perusahaan peneliti bagian pemasaran terkemuka di dunia. Dalam metode EPIC Model terdapat empat dimensi kritis, yaitu: empati, persuasi, dampak dan komunikasi (empathy, persuation, impact, and communication (EPIC).

\section{HASIL DAN PEMBAHASAN Gambaran Umum Pantai Papuma}

Papuma merupakan sebuah pantai yang terletak di Selatan Kota Jember, tepatnya di Kecamatan Wuluhan, Desa Lojejer yang berjarak sekitar $\pm 37 \mathrm{~km}$ dari kota Jember dengan suhu udara rata-rata antara $25^{\circ} \mathrm{c}-32^{\circ} \mathrm{c}$. Nama Papuma terbentuk dari akronim Pantai Pasir Putih Malikan. Sebuah objek wisata pantai dengan batu-batu karang berukuran besar yang dinamakan Batu Malikan yang tertata rapi secara alami membatasi tanah dengan pasir putih di sepanjang pantai.

Selain panorama pantai yang indah, Pantai Papuma juga dikelilingi oleh hutan seluas 25 hektar dengan berbagai macam satwa seperti biawak, ayam alas, rusa, trenggiling, dan lain sebagainya sehingga menambah kesan. Pantai Papuma memiliki garis pantai sepanjang 25 kilometer dan hutan lindung yang terbentang sepanjang pantai dengan luas sekitar 25 hektar. Adapun batas-batas 
wilayah perbatasan Pantai Papuma Jember adalah sebagai berikut:

1. Sebelah utara: Pantai Samudra Indonesia

2. Sebelah selatan: Pantai Samudera Indonesia

3. Sebelah timur: Pantai Papuma

4. Sebelah barat: Hutan Jati Perhutani dan jalan utama menuju ke Ambulu Pantai Papuma dikelola oleh Kesatuan Bisnis Mandiri, Wisata Benih dan Usaha lainnya (KBM WBU) Perum Perhutani Unit II Jatim. Sejak tahun 2006 antara kegiatan bisnis dan juga pengelolaan Papuma telah dipisahkan. Peran aktif KPH Jember dalam upaya pengembangan pariwisata lebih ditekankan pada pengembangan potensi dan sumber daya wisata yang di miliki. Di samping itu, KPH Jember mempunyai rencana pengembangan suatu objek wisata yang berkelanjutan.

Permintaan wisatawan akan penyajian baik potensi objek wisata alam maupun potensi objek wisata budaya khas masyarakat Lojejer sebagai objek wisata dan daya tarik wisata di wilayah kabupaten Jember merupakan dasar utama bagi pengembangan pariwisata alam objek wisata Pantai Papuma dan sekitarnya. Orientasi pengembangan ditetapkan sesuai dengan hasil evaluasi potensi wisata di wilayah tersebut yang merupakan tahap pendahuluan dari penyusunan perencanaan yang telah ditetapkan.

\section{Pengembangan Fisik di Objek Wisata}

\section{Pantai Papuma}

Pengembangan fisik objek wisata Pantai Papuma mencakup pembangunan sarana dan prasarana pariwisata. Adapun rencana pembangunan prasarana pariwisata meliputi:

a. Perbaikan jalan serta pengaspalan jalan menuju kawasan wisata Pantai Papuma

b. Penambahan fasilitas penginapan di sekitar lokasi objek wisata

c. Restoran dan lobi penginapan d. Penghijauan dan tanamanisasi di sekitar objek wisata Pantai Papuma dan sepanjang jalan menuju objek

e. Penambahan fasilitas hiburan khusus seperti tempat bermain (play ground)

f. Ruang ganti pakaian

g. Mushola dan toilet Umum

h. Area parkir

i. Pos keamanan / pos SAR

j. Ruang serba guna

Objek wisata alam yang direncanakan sebagai sentra aktivitas pariwisata di objek wisata Pantai Papuma sedangkan objek wisata budaya sebagai pendukung dari aktivitas objek wisata alam itu sendiri yaitu tempat untuk pementasan kesenian dan adat istiadat masyarakat untuk wisatawan. Penjualan cenderamata lewat souvenirshop, arena pelatihan seni dan kerajinan lokal baik untuk masyarakat maupun wisatawan serta aktifitas pariwisata lainnya.

2. Pengembangan Kondisi Non Fisik di Objek Wisata Pantai Papuma

Pengembangan periwisata berdasarkan karakteristiknya dapat diklasifikasikan menjadi beberapa kelompok, yaitu pariwisata alam, sosial budaya, atau pariwisata. Pengembangan non fisik yang dilakukan KPH Jawa TImur melalui KPH Jember adalah melalui rencana sebagai berikut:

a. Membangun sanggar budaya masyarakat sebagai pusat penuangan aspirasi dan pelestarian budaya

b. Pementasan kesenian sebagai atraksi wisata secara kontinue, sehingga masuk dalam kalender wisata

c. Pementasan adat istiadat sebagai daya tarik wisata. Pada umumnya adat istiadat masyarakat Wuluhan.

3. Realisasi Pengembangan Pariwisata Pantai Papuma Jember

Sebagai indikator pemerintah mengembangkan suatu daerah menjadi daerah tujuan wisata tercermin dari adanya upaya pemerintah merealisasikan beberapa kebijakan yang telah tersusun dalam rencana pengembangannya. Dalam hubungannya dengan penegembangan 
objek wisata Pantai Papuma, KPH Jawa Timur melalui KPH Jember telah merealisasikan beberapa kebijakan. Adapun beberapa realisasi dari aspek fisik (real physic) pengembangan objek wisata Pantai Papuma adalah sebagai berikut:

a. Pembuatan jalan menuju objek yang sudah cukup baik

b. Penyediaan kios cinderamata (souvenir shop) yang diperuntukan bagi wisatawan yang berkunjung ke objek wisata Pantai Papuma. Souvenir ini juga berfungsi sebagai cinderamata khas Pantai Papuma

c. Penyediaan lahan dan modal usaha bagi pengusaha warung makanan dan minuman di sekitar objek wisata Pantai Papuma

d. Membangun Musholla dan MCK

e. Menyediakan areal parkir bagi kendaraan para wisatawan

f. Menyediakan fasilitas Listrrik, air dan telepon umum bagi para wisatawan

Sedangkan upaya pengembangan dari aspek non fisik berupa program kegiatan Pekan Raya Pantai Papuma yang diselenggarakan pada tiap 1 Syawal sampai dengan 10 Syawal yang merupakan acara tradisi dalam rangka memberikan hiburan untuk masyarakat.

\section{Potensi Objek Wisata Pantai Papuma}

Sebagaimana telah dijelaskan sebelumnya bahwa potensi utama yang ditawarkan kepada wisatawan adalah potensi objek wisata alam Pantai Papuma dan merupakan daya tarik utama yang ditawarkan kepada wisatawan. Terkait dengan penawaran potensi ini memerlukan sarana dan prasarana pendukung guna memberikan kemudahan, ketenangan, keamanan serta kepuasan kepada wisatawan yang menikmati indahnya Pantai Papuma. Disisi lain, agar tidak terjadi munculnya kejenuhan perlu didukung oleh berbagai kegiatan lain seperti berperahu tradisional, kegiatan memancing, menyelam (diving), hunting (berburu), dan mendaki gunung (mountain climbing).

Sebelah timur kawasan wisata Jember terdapat gunung yang sangat tinggi dan merupakan hutan lindung. Keunikan dan budaya masyarakat dijadikan alternatif pendukung dalam memperbanyak kegiatan wisata di objek wisata Pantai Papuma. Dalam pengelolaan potensi ini sebagai penawaran kepada wisatawan Pemerintah Kabupaten Jember bersama-sama dengan pengusaha di bidang akomodasi dan restaurant menata, mempromosikan dan memasarkan objek wisata Pantai Papuma. Hal ini terkait dengan upaya pemerintah, pengembangan objek wisata Pantai Papuma misalnya adanya program rencana pengembangan fisik maupun non fisik objek wisata Pantai Papuma. Dalam sub bahasan mengenai potensi yang dimiliki akan diuraikan secara berturut mengenai potensi alam dan lingkungan, potensi Olahraga air, penginapan dan restaurant, potensi kebudayaan, dan kondisi transportasi dari objek wisata. Adapun deskripsi masingmasing potensi yang dimiliki objek wisata Pantai Papuma tersebut adalah sebagai berikut :

1. Potensi Alam dan Lingkungan

Panorama alam dan lingkungan yang dimiliki oleh objek wisata Pantai Papuma sebagai objek wisata bagi para wisatawan yang merupakan potensi utamanya adalah gelombang laut yang sangat baik untuk kegiatan wisata atau olah raga surfing yang didukung oleh pantainya yang berpasir bersih. Motivasi utama wisatawan berkunjung ke objek wisata Pantai Papuma adalah untuk menikmati keindahan alam dan situs batu ular yang ada di objek wisataPantai Papuma.

Daya tarik alam dan lingkungan objek wisata Pantai Papuma dapat dinikmati sepanjang hari maupun malam hari. Di pagi hari dapat melihat kehidupan nelayan yang menggunakan perahu-perahu 
tradisional, melihat terbitnya matahari yang sangat indah sekali dan aktifitas penduduk yang mencari kerang dengan di subuh hari untuk dijual, adalah merupakan daya tarik tersendiri bagi wisatawan.

Sedangkan pada sore hari wisatawan dapat menyaksikan para nelayan yang berangkat berlayar untuk mencari ikan dengan menggunakan perahu-perahu yang dimiliki. Pada sore hari, karena Pantai Papuma menghadap ke arah selatan sehingga wisatawan dapat menyaksikan sunset (matahari terbenam) di ufuk barat. Daya tarik alamnya yang indah umumnya disukai oleh wisatawan manca negara. Panorama alam lain yang dapat dinikmati di objek wisataPantai Papuma adalah hutan yang dikelola oleh perhutani dan berad disebelah utara dan barat kawasan wisataPantai Papuma. Di hutan ini terdapat beberapa spesies hewan yang dilindungi, diantaranya adalah spesies Orang Hutan. Hewan ini tergolong ramah kepada wisatawan, hampir sepanjang jalan yang ada di tengah-tengah hutan, wisatawan akan di goda oleh hewan ini.

2. Potensi Olah Raga Air

Kebutuhan akan fasilitas olah raga air seperti snorklin, alat scuba diving, glass bottom boat, banana boat, alat memancing, dan perlengkapan bola volly pantai kurang mendukung. Hal ini dapat dibuktikan dengan belum adanya pengusaha jasa yang bergerak khusus mengelola fasilitas olah raga air di Objek Wisata Pantai Papuma. Pemerintah Daerah kabupaten Jember melalui dinas pariwisata harus mampu memfasilitasi dan mengusahakan keberadaan fasilitas olah raga air ini dengan mengadakan kerjasama dengan para inverstor dan pengusaha jasa pariwisata. Agar dapat mendukung kegiatan potensi olah raga air tersebut, maka perlu sekali fasilitas olah raga air tersebut direalisasiakan keberadaannya agar dapat mendukung potensi yang dimiliki.

3. Penginapan dan Restoran

Dengan adanya kelengkapan sarana penunjang akan dapat memberikan kemudahan-kemudahan dalam menikmati suatu objek wisata. Sarana penunjang tersebut seperti hotel dan restauran. Untuk kawasan wisata Pantai Papuma Jember sarana akomodasi penginapan dan restauran belum memadai. Dulunya pernah ada hotel dan restauran dengan kategori melati di Objek Wisata Pantai Papuma Jember, yaitu Hotel Wisnu tetapi karena ada masalah dengan warga sekitar, hotel dan restauran dinyatakan ditutup oleh pemiliknya.

4. Potensi Kebudayaan

Optimalisasi pendayagunaan kebudayaan sebagai daya tarik wisata (tourist attraction) dalam bentuk objek wisata maupun atraksi wisata akan memberikan peluang bagi perkembangan pariwisata di kabupaten Jember umumnya, dan objek wisata Pantai Papuma khususnya. Unsur-unsur kebudayaan yang ditawarkan dalam bentuk atraksi yang ada dan dapat dikembangkan di kawasan wisata Pantai Papuma, serta dapat menarik wisatawan untuk datang adalah atraksi alam dan budaya.

a. Atraksi alam yang dimiliki oleh objek wisata Pantai Papuma adalah pesona alam dan debur ombak, angin laut selatan, panorama kepulauan yang dapat dilihat dari Pantai Papuma, dan sebagainya. Atraksi alam yang dimiliki oleh objek sebagian besar masih alami. Hal tersebut dapat dilihat dari kondisi alamnya yang 90\% masih berupa lahan kosong yang ditanami dengan tanaman pantai misalnya pohon kelapa, 
ketapang, pandan laut dan jenisjenis lainnya. Namum kondisi tanamannya masih membutuhkan pemeliharaan khusus agar kawasannya menjadi lebih hijau, nyaman dan sejuk.

b. Upacara Larung Saji. Upacara ini merupakan upacara yang setiap tahun dilakukan oleh nelayan di wilayah Jember. Upacara ini adalah tanda dimulainya panen raya penangkapan ikan yang dimulai sekitar bulan April dan Mei setiap tahunnya. Upacara ini juga dimaksudkan untuk memohon perlindungan kepada Tuhan Yang Maha Esa agar selama berlayar para nelayan diberkahi rejeki dan dilindungi dari segala bencana, dan juga sebagai ungkapan rasa syukur atas rahmat yang telah dilimpahkannya berupa ikan dan hasil laut lainnya serta memohon keselamatan terhadap sumber daya laut yang ada agar selalu lestari. Prosesi upacara Larung Saji ditandai dengan bermacam sesaji utama berupa kepala kerbau. Bentuk dari atraksi dari Larung Saji dilakukan selama beriring-iringan.

5. Tingkat Aksesibilitas

Dalam hal ini yang dimaksud dengan tingkat aksesibilitas adalah tingkat kemudahan atau transportasi dalam mencapai objek wisata Pantai Papuma. Adapun tingkat aksesibilitas dapat diukur berdasarkan:

a. Kondisi Jalan

Kondisi jalan dalam hal ini ada dua yaitu kondisi jalan utama dan kondisi jalan setapak menuju objek. Kondisi jalan utama saat ini yang dari arah Kota Jember sampai Kecamatan Wuluhan sampai dengan Ambulu cukup bagus dan memadai untuk memberikan kenyamanan bagi para wisatawan yang berkunjung ke objek wisataPantai Papuma Jember.
Demikianpun dengan kondisi lebar jalan sudah memadai. Pada umumnya wisatawan yang berkunjung di objek ini sebagian besar membawa mobil pribadi dan mobil sewaan (rent car) atau mobil mini bus yang disediakan oleh biro perjalanan wisata. Tetapi banyak juga di antara wisatawan yang mengunjungi objek wisataPantai Papuma menggunakan kendaraan umum (Lin) dan ketika sampai di daerah Ambulu dapat menggunakan jasa Angkutan Pedesaan atau dengan jasa Ojek. Sedangkan untuk kondisi jalan menuju dan di daerah objek wisata, KPH Jawa TImur melalui $\mathrm{KPH}$ Jember sudah membangun jalan aspal yang dibertujuan memberikan kepuasan dan kenyamanan kepada wisatawan baik mancanegara maupun wisatawan domestik agar berkunjung ke objek wisata Pantai Papuma. Faktor jalan memang menjadi aspek penting pertimbangan wisatawan dalam mengunjungi suatu objek wisata. Kemudahan mengakses dan menjangkau suatu objek akan memberikan kesan tersendiri bagi wisatawan untuk berkunjung kembali.

b. Jarak dan Waktu Untuk mengetahui jarak dan waktu tempuh serta pencapaian dari berbagai tempat menuju objek dapat dilihat pada tabel 4.4 di bawah ini : 
Tabel 4.4. Jarak dan Waktu Tempuh Menuju Objek wisata Pantai

Papuma Jember

\begin{tabular}{|c|c|c|c|}
\hline No. & Dari Kota & $\begin{array}{c}\text { Waktu } \\
\text { Tempuh } \\
\text { (Jam) }\end{array}$ & Kendaraan \\
\hline 1 & Surabaya & $5-6$ & Roda $2-4$ \\
\hline 2 & Banyuwangi & $3-4$ & Roda $2-4$ \\
\hline 3 & Bondowoso & $2-3$ & Roda $2-4$ \\
\hline 4 & Lumajang & $2-3$ & Roda $2-4$ \\
\hline 5 & Probolinggo & $3-4$ & Roda $2-4$ \\
\hline
\end{tabular}

Sumber : Pusat Informasi Pariwisata

Dinas Pariwisata Jember

c. Biaya

Adapun biaya yang dimaksud adalah sejumlah biaya atau ongkos yang dipergunakan oleh wisatawan untuk mencapai objek wisata Pantai Papuma. Pengukuran biaya di sini sangatlah abstrak karena dipengaruhi oleh jarak tempuh, jenis transportasi yang digunakan, ada tidaknya wisatawan yang makan dan minum serta berbelanja di tempat yang dikunjungi dan sebagainya yang keseluruhannya sulit ditentukan nilai riilnya. Untuk tiket masuk ke objek wisata Pantai Papuma, wisatawan hanya mengeluarkan ongkos Rp 5.000 pada hari biasa, dan $\mathrm{Rp} 7.000$ pada hari minggu dan hari-hari libur lainnya.

\section{Kegiatan Promosi Dan Pemasaran Pantai Papuma}

Informasi dan promosi merupakan aspek penting dalam upaya pengembangan suatu objek wisata. Maksud dilakukan promosi dan informasi antara lain adalah:

1. Memperkenalkan potensi atraksi yang dimiliki oleh suatu objek wisata. Apakah potensi atraksi alam, atraksi budaya ataukah atraksi khusus
2. Memberikan informasi mengenai akses dan fasilitas penunjang yang ada di kawasan objek wisata tersebut

3. Memberikan informasi aktivitas apa saja yang dapat dilakukan, dan lain sebagainya.

Informasi dan promosi terhadap potensi wiasata di Pantai Papuma, merupakan upaya dalam memperkenalkan objek wisata Pantai Papuma dengan pembuatan boklet, pameran dan brosur dan melalui media lainnya. Di samping itu ditunjang dengan bentuk informasi yang lain, yaitu pemasangan penunjuk jalan atau iklan di pinggir jalan. Upaya untuk pelaksanaan informasi dan promosi pengembangan wisata Pantai Papuma sudah dapat dikatakan telah dilaksanakan oleh KPH Jawa Timur melalui KPH Jember.

\section{Efektivitas Promosi Pantai Papuma}

Berdasarkan pengolahan data melalui teknik analisa EPIC Model diperoleh hasil pengukuran pernyataan atribut dimensi empati, persuasi, dampak, dan komunikasi, diperoleh total skor rataan sebesar 4,16 untuk dimensi empati adalah 4,20, sedangkan untuk dimensi persuasi adalah 3,83 , selanjutnya untuk dimensi dampak adalah 3,83, dan skor sebesar 3,92 untuk dimensi komunikasi (Tabel 4.4). Dari total skor rataan pendapat respoden atas pernyataanpernyataan yang mengukur dimensi empati didapat hasil sebesar 4,16.

Nilai tersebut berada pada rentang skala dimana dimensi empati suatu iklan dinyatakan efektif. Hal ini dapat diartikan bahwa responden secara umum mempersepsikan iklan/promosi Pantai Papuma di media jejaring sosial adalah bagus dan menyukai iklan/promosi Pantai Papuma di media jejaring sosial.

Dimensi persuasi memperoleh skor rataan terbesar yaitu sebesar 4,20. Nilai ini berada pada rentang skala dimana dimensi persuasi suatu iklan dinyatakan efektif dalam mempengaruhi pengguna jejaring sosial. Hal ini dapat diartikan bahwa 
responden secara umum tertarik dengan obyek wisata Pantai Papuma dan ingin mengunjungi obyek wisata Pantai Papuma.

Dimensi dampak memperoleh skor rataan sebesar 3,83 . Nilai ini juga berada pada rentang skala efekif. Hal ini menunjukkan bahwa iklan dianggap efektif untuk membuat para para pengguna ingat akan iklan obyek wisata Pantai Papuma di jejaring sosial dibandingkan pesaingnya. Dimensi dampak memperlihatkan bahwa mempromosikan obyek wisata Pantai Papuma melalui iklan di jejaring sosial efektif. Iklan yang ditampilkan memiliki dampak positif yang dapat diterima baik oleh para wisatawan sehingga wisatawan dapat mengetahui betul tentang obyek wisata Pantai Papuma dan iklan/promosi obyek wisata Pantai Papuma di media jejaring sosial menarik perhatian wisatawan.

Total skor rataan pendapat respoden atas pernyataan yang mengukur dimensi komunikasi adalah 3,92. Nilai tersebut berada pada rentang skala dimana dimensi komunikasi suatu iklan dinyatakan efektif. Hal ini dapat diartikan bahwa iklan obyek wisata Pantai Papuma mempunyai pesan yang kuat bagi pengguna jejaring sosial yang melihat iklan tersebut. Hal ini dapat diketahui dari persepsi responden yang menyatakan bahwa iklan/promosi Pantai Papuma di media jejaring sosial lebih menarik dibandingkan dengan iklan sejenis di media jejaring sosial, iklan Pantai Papuma di media jejaring sosial memberikan informasi yang dibutuhkan wisatawan, wisatawan mengerti Pantai Papuma adalah obyek wisata alam yang harus dijaga kelestariannya, dan slogan Wana Wisata Pantai Papuma sudah mencerminkan kondisi saat ini.

Secara keseluruhan nilai setiap dimensi dapat dipetakan pada Model EPIC rate (Gambar 4.1). Gambar grafik hasil analisis efektivitas iklan obyek wisata Pantai Papuma di jejaring sosial dengan metode EPIC model secara keseluruhan dapat dilihat pada Gambar 4.1 berikut.

Gambar 4.1 Grafik EPIC Model Iklan Objek Wisata Pantai Papuma

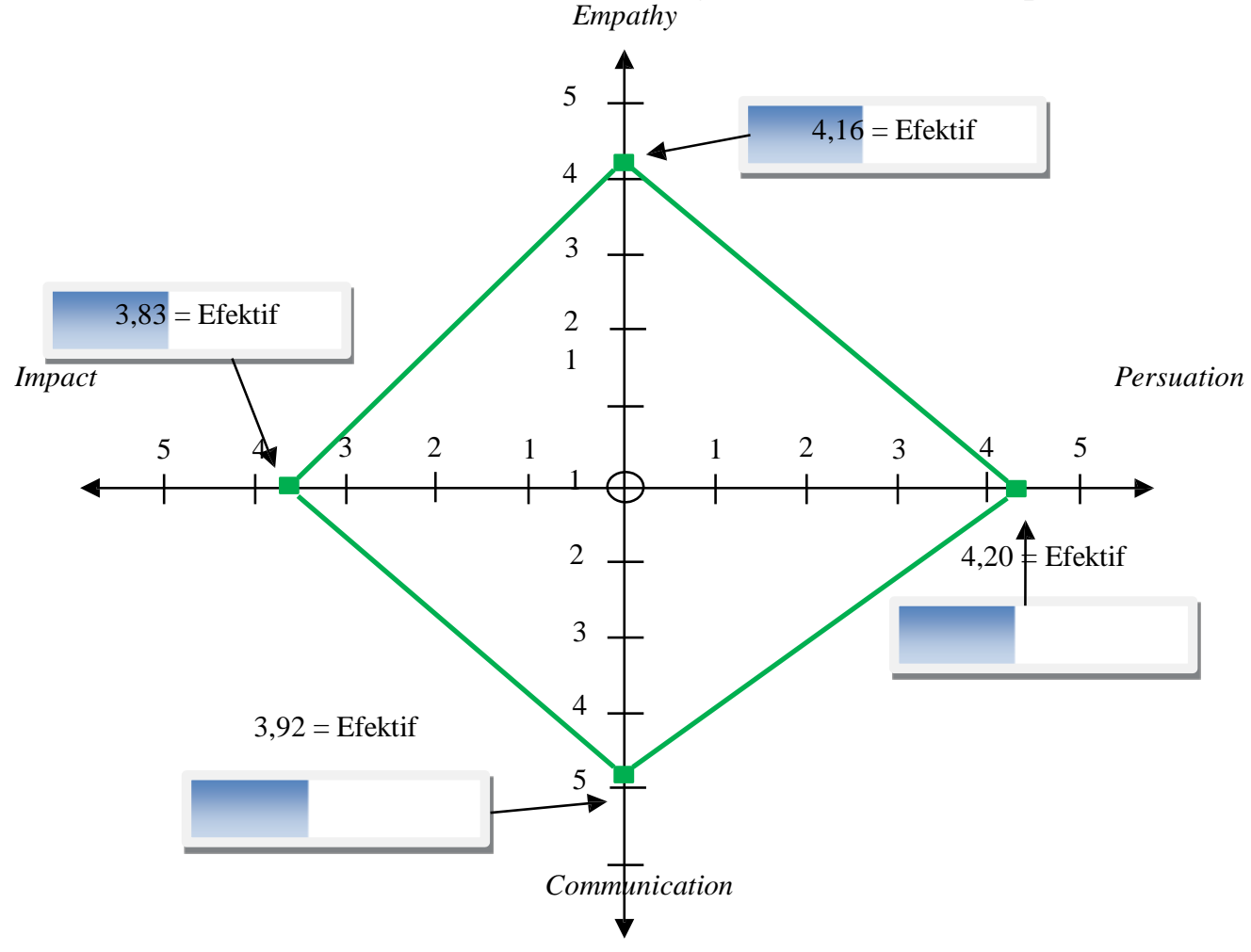


Berdasarkan Gambar 4.1 diketahui bahwa efektivitas iklan obyek wisata Pantai Papuma jika diukur menggunakan metode EPIC model yang terdiri dari 4 dimensi (Empathy, Persuasion, Impact, dan Communication) menunjukkan hasil yang efektif pada setiap dimensi. Hal ini menunjukkan bahwa:

1. Responden menganggap iklan ini bagus (menarik), dan menyatakan kesukaannya terhadap iklan Pantai Papuma di media jejaring sosial tersebut (empathy).

2. Responden menilai bahwa iklan ini efektif dalam mempengaruhi pengguna jejaring sosial. Dalam hal ini responden secara umum tertarik dengan obyek wisata Pantai Papuma dan ingin mengunjungi obyek wisata Pantai Papuma (persuasion).

3. Responden pun menilai bahwa melalui iklan ini wisatawan dapat mengetahui betul tentang obyek wisata Pantai Papuma dan iklan/promosi obyek wisata Pantai Papuma di media jejaring sosial menarik perhatian wisatawan (impact).

4. Responden dapat dengan baik dalam memahami dan menangkap pesan utama yang disampaikan dalam iklan obyek wisata Pantai Papuma tersebut. Dalam hal ini responden menyatakan iklan/promosi Pantai Papuma di media jejaring sosial lebih menarik dibandingkan dengan iklan sejenis di media jejaring sosial, iklan Pantai Papuma di media jejaring sosial memberikan informasi yang dibutuhkan wisatawan, wisatawan mengerti Pantai Papuma adalah obyek wisata alam yang harus dijaga kelestariannya, dan slogan Wana Wisata Pantai Papuma sudah mencerminkan kondisi saat ini (communication).

\section{SIMPULAN}

Berdasarkan hasil pembahasan diatas, penulis mendapatkan kesimpulan sebagai berikut:

1. Pengukuran terhadap dimensi empathy menunjukkan bahwa iklan ini masuk dalam rentang skala cukup efektif. Hal ini mengindikasikan bahwa iklan Pantai Papuma di media jejaring sosial tersebut mampu memberikan informasi dan pesan yang menarik sehingga cukup disukai.

2. Pengukuran terhadap dimensi persuasion menunjukkan bahwa iklan ini masuk dalam rentang skala cukup efektif. Hal ini mengindikasikan iklan tersebut dapat mempengaruhi pengguna jejaring sosial, sehingga responden secara umum tertarik dengan obyek wisata Pantai Papuma dan ingin mengunjungi obyek wisata Pantai Papuma.

3. Pengukuran terhadap dimensi impact menunjukkan bahwa iklan ini masuk dalam rentang skala cukup efektif. Dalam hal ini wisatawan dapat mengetahui betul tentang obyek wisata Pantai Papuma dan iklan/promosi obyek wisata Pantai Papuma di media jejaring sosial menarik perhatian wisatawan.

4. Pengukuran terhadap dimensi communication menunjukkan bahwa iklan ini masuk dalam rentang skala cukup efektif. Hal Hal ini mengiindikasi bahwa iklan/promosi Pantai Papuma di media jejaring sosial lebih menarik dibandingkan dengan iklan sejenis di media jejaring sosial, selain itu iklan Pantai Papuma di media jejaring sosial memberikan informasi yang dibutuhkan wisatawan sehingga wisatawan mengerti Pantai Papuma adalah obyek wisata alam yang harus dijaga kelestariannya dan slogan 
Wana Wisata Pantai Papuma sudah mencerminkan kondisi saat ini.

\section{DAFTAR PUSTAKA}

Anwar, Chairil. 2010. Analisis Pengaruh Faktor Kompensasi, Motivasi Dan Lingkungan Kerja Terhadap Kinerja Karyawan Melalui Kepuasan Kerja Di Hotel Bintang Mulia Jember.

Arikunto, Suharsami. 1993. Prosedur Penelitian Suatu Pendekatan Praktek., Jakarta : Rineka Cipta

Durianto, D., Sugiarto., Widjaja, A.W., Supratikno, H. (2003). Invasi Pasar Dengan Iklan Yang Efektif. Jakarta: PT. Gramedia Pustaka Indah.

Handoko, T., Hanni, 1994. Manajemen Personalia dan Sumber Daya Manusia. Yogyakarta: BPFE

Komariah. 2006. Pengaruh Kompensasi Terhadap Kinerja Karyawan. Tesis. Fakultas Ekonomi, Universitas Bina Darma Palembang.

Rivai. 2004. Manajemen Sumber Daya Manusia Untuk Perusahaan, Cetakan pertama, Raja Grafindo Persada Robbins, Stephen, P. 2001. Perilaku Organisasi. Edisi Indonesia, Jakarta : PT. Prenhallindo.

Setyowati, Trias. 2011. Pengaruh Faktor Motivasi, Kompensasi Dan Disiplin Kerja Terhadap Kinerja Karyawan Melalui Kepuasan Kerja Di Universitas Muhammadiyah Jember. Tesis. Jember: UNEJ

Simamora, H. 2004. Manajemen Sumber Daya Manusia. STIE YKPN: Yogyakarta

Singarimbun, Masri dan Effendi, Sofian.1995. Metode Penelitian Survei. Jakarta : LP3ES

Sudarmadi, 2007, Analisis Pengaruh Budaya Organisasi Dan Gaya Kepemimpinan Terhadap Kepuasan Kerja Dan Kinerja Karyawan, Tesis. Semarang: UNDIP.

Supriyadi, Andhi, 2005, Analisis Pengaruh Kepuasan Kompensasi,
Pemberdayaan dan Budaya Organisasi Terhadap Kinerja Karyawan, Tesis, Semarang: UNDIP.

Tias, Ratnaning Santi. 2006. VariabelVariabel Yang Mempengaruhi Kinerja Pegawai Kantor Polisi Pamong Praja Kabupaten Jember. Karya Tulis Utama. Magister Manajemen. Program Pasca Sarjana Universitas Jember

Mangkunegara. 2002. Manajemen Sumber Daya Manusia Perusahaan. Bandung: Remaja Rosdakarya.

Mursalim, (2013). Analisis Efektivitas Iklan Media Online Pada PT Surveyor Indonesia Kanwil Makassar. Skripsi. Makassar. Universitas Hasanuddin

Priadi, Rudi. 2010. Analisis Efektivitas Iklan Yamaha Jupiter Mx Versi "Merobohkan Jembatan" Terhadap Dampak Komunikasi Diukur dengan Metode EPIC Model. Journal Vol 2. Diakses dari http://portal.kopertis3.or.id/ handle/123456789/1056 